\title{
Process Optimization of Turkey Meat Sausages by using Raw Radish Paste
}

\author{
M. Naveen Kumar Reddy, M. Shashi Kumar, G. V. Bhaskar Reddy*, \\ N. Krishnaiah, N. Anitha Reddy and D. Maheswara Reddy
}

Department of Livestock Products Technology, College of Veterinary Science, PVNR Telangana Veterinary University, Rajendranagar-500 030, India

*Corresponding author

\section{Keywords}

Turkey meat sausages, Radish Paste, Physicochemical quality and Sensory Evaluation

\section{Article Info}

Accepted:

17 June 2020

Available Online:

10 July 2020

\begin{abstract}
A B S T R A C T
A study was undertaken to determine the effect of incorporation of raw radish paste (RRP) in turkey meat sausages. Standardized recipe containing turkey lean meat (85\%), vegetable oil $(15 \%)$ was considered as control. Raw radish paste (RRP) was incorporated replacing lean meat in turkey meat sausages at 3 levels i.e., 5, 10 and 15 percent and evaluated for physico-chemical, proximate composition and organoleptic quality. Addition of $10 \%$ raw radish paste $(\mathrm{RRP})$ significantly $(\mathrm{P}<0.05)$ variable in emulsion $\mathrm{pH}$ and product $\mathrm{pH}$. Control sausages had significant $(\mathrm{P}<0.05)$ higher emulsion and product $\mathrm{pH}$ values than $\mathrm{RRP}$ added sausages. Addition of RRP significantly $(\mathrm{P}<0.05)$ lower emulsion stability and cooking yield compared to addition of various concentrations of RRP. Addition of $15 \%$ RRP significantly $(\mathrm{P}<0.05)$ increased moisture and crude fibre per cent and reduced crude protein and ether extract than control and remaining formulations of turkey meat sausages. Addition of different concentrations of RRP significantly $(\mathrm{P}<0.05)$ variable in different sensory scores of turkey meat sausages. Turkey meat sausages added with $10 \%$ raw radish paste had significantly $(\mathrm{P}<0.05)$ higher overall acceptability scores than control and remaining formulations. Based on the results of sensory evaluation, turkey meat sausages added with $10 \%$ RRP had better acceptable than remaining formulations.
\end{abstract}

\section{Introduction}

Consumption of meat containing high amounts of polyunsaturated fatty acids (PUFAs) has increased greatly in the last decade due to recommendations of nutritionists to reduce intake of saturated fatty acids. Turkey meat is one of the leanest types of poultry meat because of the low fat and is a good source of protein (Castro Ferreira et al., 2000). Turkey meat is an excellent source of several important vitamins and nutrients such as iron, niacin, zinc, potassium, and $\mathrm{B}$ complex vitamins. It contains high level of monounsaturated and polyunsaturated fats which help to lower the levels of LDL cholesterol in blood. Turkey meat is easier to digest than other types of meat, which makes it a good choice for individuals who have digestive problems (Otles and Cagindi, 2008). A wide variety of non-meat ingredients are being utilized as extenders, binders or fillers in comminuted meat products. In recent years, some fruits and vegetables have gained the 
importance in functional foods, as they are a rich source of natural antioxidants, dietary fibers, essential minerals and vitamins (Yue, 2001). So far, very limited research work has been conducted on suitability and antioxidant potential of vegetables like carrot and radish in comminuted meat products.

Incorporation of vegetables in processed meat products would serve as substitute for nonmeat ingredients that will bring substantial cost reduction and also improve the nutritive value. Radish is a root plant related to the mustard family and it is one of the richest sources of iron and calcium amongst all common vegetables. The main constituents of radish are 4-methylthio)-3-butenyl isothiocyanate, allyl isothiocyanate, benzyl isothiocyanate, and phenethyl isothiocyanate. It also contains flavonoids such as kaempherol glycosides, peroxidases and antioxidants. The previous studies reported that Radish sativus extract showed antimicrobial (Esaki and Onozaki, 1982), antimutagenic and anticarcinogenic effects. Takaya et al., (2003) suggested that crude extract of radish is also known to contain antioxidant enzyme activities and the antioxidant L-tryptophan was isolated from radish extract (Katsuzaki et al., 2004). Radish is an excellent source of vitamin $C$, potassium, folate and magnesium. Vitamin $\mathrm{C}$ present in radish root is powerful antioxidant and anti-inflammatory agent (Gushi et al., 1983). Due to paucity of information on usage of radish in comminuted meat products the following work aimed to investigate the effect of radish on quality characteristics turkey meat sausages.

\section{Materials and Methods}

\section{Source of raw material}

Tom turkey birds (Broad Breasted White) of 25-30 weeks of age were procured from the
Poultry Research Station, Rajendranagar, Hyderabad slaughtered and dressed adopting standard procedure at the Department of Livestock Products Technology, College of Veterinary Science, Rajendranagar, Hyderabad. Carrot and Radish were procured from local vegetable market, washed with tap water for cleaning and removal of extraneous dirt. The cleaned vegetables were peeled manually with peeler, cut into slices and were made into a paste by using a home mixer / grinder and analytical grade chemicals and food grade additives were procured from standard companies.

\section{Preparation of turkey meat sausages}

The turkey meat was minced using meat mincer (Model: Sirman TC 32 Colorado, Italy) using $8 \mathrm{~mm}$ plate followed by $4 \mathrm{~mm}$ plate. Sausages were prepared using ingredients as per the recipe presented in Table-1 viz., Control, Carrot and Radish incorporated each at $10 \%$ level replacing lean meat. Emulsion was prepared in Bowl Chopper (Model: MADO Garrant MTK 661, Germany).The fresh boneless turkey meat cut into small chunks and minced in a meat mincer (Sirman,TC $12 \mathrm{E}$, Italy) through $4 \mathrm{~mm}$ plate. The emulsion was prepared by chopping the minced meat along with othernon-meat ingredients in a bowl chopper (Scharfen, Model No: TC 11, Germany). The minced chicken meat was mixed with salt @ $1.5 \%$, STPP @ $0.4 \%$, sodium nitrate @ 150 ppm, sodium ascorbate @ 500 ppm, sugar @ $1 \%$ and ice flakes @ $8 \%$ and chopped for one min followed by addition of oil @ $6 \%$ and again chopped for one min and added corn flour @3\%, spice mix @ 1.6, condiment mix@3\% (onion and garlic: 3:1), radish paste @ 0,5,10 and 15\% in control, T1, T2 and T3 sausages and finally chopped for $3 \mathrm{~min}$. The temperature of the emulsion was maintained between 12 to $15^{\circ} \mathrm{C}$. The emulsions of control, $\mathrm{T} 1$ and $\mathrm{T} 2$ was 
separately stuffed into synthetic cellulose casings (SCC21) using horizontal sausage stuffer and cooked at $80^{\circ} \mathrm{C} / 20 \mathrm{~min}$ in moist heat. After cooking the sausages were cooled to room temperature and chilled under refrigeration for few minutes then immediately subjected them to quality analysis i.e. physico-chemical characteristics like cooking yield, emulsion stability, $\mathrm{pH}$, proximate analysis and organoleptic evaluation.

\section{Analytical Parameters}

The $\mathrm{pH}$ of the emulsion was determined by following the procedure of Trout et al., (1992).Emulsion stability was carried out by adopting method of Townsend et al., (1968).Percentage of cooking yield was determined by calculating differences in weight of the sausages before and after cooking as per the method suggested by Murphy et al., (1975). The proximate analysis was conducted as per the procedures outlined by AOAC (1995). Sensory evaluation of the product was carried out on a 9 point hedonic scale by a semi trained five members taste panel as per the procedure described by Keeton, (1983). The data thus obtained was subjected to statistical analysis using SPSS MAC, version 20.0, SPSS Chicago (US).

\section{Results and Discussion}

\section{Physico-chemical characteristics}

The influence on RRP on physic-chemical characteristics of turkey meat sausages are presented in Table 01.

\section{pH}

There was a significant difference $(\mathrm{P}<0.05)$ in the $\mathrm{pH}$ of control and emulsion incorporated with different levels of RRP. A significant decrease $(\mathrm{P}<0.05)$ in the $\mathrm{pH}$ of the emulsion was observed as the incorporation level of RRP increased from 5 to $15 \%$ which might be due to the lower $\mathrm{pH}$ and slight acidic nature of radish paste. Similar findings were observed by Grigelmo-Miguel et al., (1999) in meat products formulation and Verma et al., (2012) in chicken nuggets incorporated with bottle gourd.

\section{Emulsion Stability}

There was a significant difference $(\mathrm{P}<0.05)$ in the emulsion stability of control and turkey meat sausages added with raw radish paste. A significant decrease $(\mathrm{P}<0.05)$ in the emulsion stability of the sausages was recorded as the incorporation level increased from 5 to 15 $\%$.This might be due to the interaction of water molecules of radish with meat proteins thereby reducing the emulsion stability. The probable reasons for the decreased emulsion stability dueto radish inclusion could be attributed to the linear decrease in $\mathrm{pH}$, poor fat binding capacity of radish and interference in the formation of a uniform and stable emulsion. A similar decrease in emulsion stability was also reported by Verma et al., (2012) in various meat products and Zargar et al., (2017) in carrot incorporated chicken sausages.

\section{Cooking Yield}

Highest cooking yield was observed in control. A significant decrease $(\mathrm{P}<0.05)$ in the cooking yield of the sausages recorded as the incorporation level of RRP increased from 5 to $15 \%$.This could be due to formation of comparatively less stable emulsion in the formulations containing RRP. Low emulsion stability may have resulted in more loss of moisture during cooking. Similar findings were observed by Verma et al., (2012) in chicken nuggets incorporated with bottle gourd and Zargar et al., (2017) in carrot incorporated chicken sausages. 


\section{Proximate composition}

The data recorded on proximate composition viz., percent moisture, crude protein, crude fat, total ash and crude fibre are presented in Table 2. Perusal of results presentation showed that there was a significant $(\mathrm{P}<0.05)$ increase in the percentage of moisture as the incorporation level of RRP increased from 5 to $15 \%$. This might be due to comparatively higher moisture content in the RRP, higher water retention capacity of these fibers, the soluble component of which mainly is pectin that may constitute upto $30 \%$ of the fibers concentrate. These results were in agreement with the findings of Kaur et al., (2015) in chicken nuggets and Zargar et al., (2017)) in vegetable incorporated meat products.

Table.1 Effect of incorporation of different levels of raw radish paste on physico-chemical properties of Turkey meat sausages (Mean \pm SE)

\begin{tabular}{|c|c|c|c|c|}
\hline & & \multicolumn{3}{|c|}{ Treatment } \\
\hline Parameters & Control & $\mathbf{5 \%}$ RRP & $\mathbf{1 0}$ \% RRP & 15 \% RRP \\
\hline Emulsion pH & $6.05 \pm 0.01^{\mathrm{a}}$ & $5.98 \pm 0.02^{\mathrm{b}}$ & $5.92 \pm 0.02^{\mathrm{bc}}$ & $5.84 \pm 0.03^{\mathrm{c}}$ \\
\hline Product pH & $6.31 \pm 0.08^{\mathrm{a}}$ & $6.26 \pm 0.04^{\mathrm{b}}$ & $6.20 \pm 0.03^{\mathrm{c}}$ & $6.14 \pm 0.07^{\mathrm{d}}$ \\
\hline Emulsion stability (\%) & $96.08 \pm 0.39^{\mathrm{a}}$ & $94.10 \pm 0.34^{\mathrm{b}}$ & $93.44 \pm 0.58^{\mathrm{bc}}$ & $92.58 \pm 0.50^{\mathrm{c}}$ \\
\hline Cooking yield (\%) & $95.32 \pm 0.33^{\mathrm{a}}$ & $94.50 \pm 0.36^{\mathrm{ab}}$ & $93.64 \pm 0.38^{\mathrm{b}}$ & $92.64 \pm 0.40^{\mathrm{c}}$ \\
\hline
\end{tabular}

Means with different superscripts in the same row differed significantly $(\mathrm{P}<0.05)$

Table.2 Effect of incorporation of different levels of raw radish paste on proximate composition of Turkey meat sausages (Mean \pm SE)

\begin{tabular}{|c|c|c|c|c|}
\hline & & \multicolumn{3}{|c|}{ Treatment } \\
\hline Parameters & Control & $\mathbf{5 \% ~ R R P ~}$ & $\mathbf{1 0 \% \text { RRP }}$ & $\mathbf{1 5 \%}$ RRP \\
\hline Moisture (\%) & $61.62 \pm 0.22^{\mathrm{d}}$ & $62.50 \pm 0.38^{\mathrm{c}}$ & $63.46 \pm 0.28^{\mathrm{b}}$ & $64.28 \pm 0.46^{\mathrm{a}}$ \\
\hline Crude protein (\%) & $18.63 \pm 0.20^{\mathrm{a}}$ & $17.87 \pm 0.23^{\mathrm{a}}$ & $17.11 \pm 0.15^{\mathrm{ab}}$ & $16.22 \pm 0.17^{\mathrm{b}}$ \\
\hline Ether extract (\%) & $15.45 \pm 0.15^{\mathrm{a}}$ & $15.06 \pm 0.14^{\mathrm{a}}$ & $14.55 \pm 0.14^{\mathrm{b}}$ & $13.97 \pm 0.20^{\mathrm{c}}$ \\
\hline Total ash (\%) & $2.20 \pm 0.05^{\mathrm{a}}$ & $2.14 \pm 0.06^{\mathrm{a}}$ & $2.09 \pm 0.03^{\mathrm{ab}}$ & $2.02 \pm 0.02^{\mathrm{b}}$ \\
\hline Crude fibre (\%) & $1.40 \pm 0.01^{\mathrm{d}}$ & $1.63 \pm 0.03^{\mathrm{c}}$ & $1.83 \pm 0.02^{\mathrm{b}}$ & $2.01 \pm 0.03^{\mathrm{a}}$ \\
\hline
\end{tabular}

Means with different superscripts in the same row different significantly $(\mathrm{P}<0.05)$

Table.3 Effect of incorporation of different levels of raw radish paste on the sensory evaluation of Turkey meat sausages (Mean \pm SE)

\begin{tabular}{|c|c|c|c|c|}
\hline & & \multicolumn{3}{|c|}{ Treatment } \\
\hline Parameters & Control & $\mathbf{5 \% ~ R R P ~}$ & $\mathbf{1 0}^{\text {\% RRP }}$ & $\mathbf{1 5}^{\text {\% }} \mathbf{R R P}$ \\
\hline Appearance & $7.28 \pm 0.01^{\mathrm{b}}$ & $7.35 \pm 0.02^{\mathrm{a}}$ & $7.38 \pm 0.03^{\mathrm{a}}$ & $7.42 \pm 0.03^{\mathrm{a}}$ \\
\hline Flavour & $7.43 \pm 0.04^{\mathrm{a}}$ & $7.34 \pm 0.02^{\mathrm{ab}}$ & $7.32 \pm 0.04^{\mathrm{b}}$ & $6.84 \pm 0.05^{\mathrm{c}}$ \\
\hline Texture & $7.06 \pm 0.07^{\mathrm{c}}$ & $7.21 \pm 0.03^{\mathrm{b}}$ & $7.34 \pm 0.02^{\mathrm{a}}$ & $7.38 \pm 0.03^{\mathrm{a}}$ \\
\hline Juiciness & $7.03 \pm 0.05^{\mathrm{c}}$ & $7.11 \pm 0.07^{\mathrm{b}}$ & $7.23 \pm 0.06^{\mathrm{a}}$ & $7.26 \pm 0.07^{\mathrm{a}}$ \\
\hline Overall acceptability & $7.23 \pm 0.03^{\mathrm{b}}$ & $7.28 \pm 0.02^{\mathrm{b}}$ & $7.39 \pm 0.04^{\mathrm{a}}$ & $7.12 \pm 0.02^{\mathrm{c}}$ \\
\hline
\end{tabular}

Means with different superscripts in the same row differed significantly $(\mathrm{P}<0.05)$ 
Protein percent decreased in all treated products when compared to control with the increasing levels of radish paste from 5 to 15 $\%$ as there was negligible protein content in radish paste. Similar results were reported by Verma et al., (2013) and Mendiratta et al., (2013) in various meat products.

Gradual decline in fat content was observed as the incorporation of radish level increased. Brauer (1994) also reported that fat and moisture content are very closely related in meat products and if fat content is low, the moisture content is likely to be high. Kaur et al., (2015) and Zargar et al., (2017) found similar results indifferent meat products. A non-significant $(\mathrm{P}>0.05)$ decrease in the percentage of ash as the incorporation level of RRP increased from 5 to $10 \%$ compared to control but differed significantly with $15 \%$ replacement of RRP. These results are in agreement with Zargar et al., (2017)) in chicken sausages.A significant $(\mathrm{P}<0.05)$ increase in the percentage of crude fibre was observed as the incorporation level of RRP increased from 5 to $15 \%$. This increase in crude fiber might be due to high fiber level present in radish. This was found in agreement with the results of Verma et al., (2013) and Das et al.,(2013) in various meat products.

\section{Sensory evaluation}

The cooked turkey meat sausages incorporated with different levels of raw radish paste and control samples were presented in the Table 3.

The appearance score for the sausages incorporated with different levels of raw radish paste and control were between very desirable to moderately desirable as per hedonic scale ranging from 7.28 to 7.42 . A significant difference $(\mathrm{P}<0.05)$ observed in the appearance of control and sausages incorporated with different levels of RRP but it not among the levels of incorporation of RRP.

The flavour scores of the sausages incorporated with different levels of raw radish paste and control varied between very desirable to moderately desirable as per hedonic scale with corresponding scores ranging from 7.43to 6.84. There was a significant differences $(\mathrm{P}<0.05)$ in the flavour score of sausages with the increased levels of incorporation of raw radish paste and control. However, the flavour scores were numerically lower in $15 \%$ level when compared to that of control which might be attributed to raw radish flavour.

The sausages incorporated with RRP recorded significantly $(\mathrm{P}<0.05)$ higher texture scores compared to control (7.06). The texture scores improved upon incorporation of raw radish paste. The texture scores of the treated sausages were between very desirable to moderately desirable as per hedonic scale with score ranging from 7.06 to 7.38.It might be due to property of added fibre which has unique characteristics in building texture, due to their ability to bind water and form gels.

The score for juiciness of the sausages incorporated with different levels of raw radish paste were between very desirable to moderately desirable as per hedonic scale with score ranged from 7.03 to 7.26. The juiciness scores of sausages incorporated with different levels of RRP were significantly $(\mathrm{P}<0.05)$ higher compared with control and the juiciness scores increased with increased levels of incorporation of raw radish paste. Higher juiciness scores in the products with increase in the level of RRP could be possibly due to high moisture content of radish.

The overall acceptability of control did not differ significantly with $5 \%$ replaced RRP 
emulsion but differed significantly with 10 and $15 \%$ replacements. There was a significant difference $(\mathrm{P}<0.05)$ between 10 and $15 \%$ replacements. The results obtained in the study were in accordance with Serdaroglu (2006) in beef patties, Chang et al.,(2010) in Chinese style sausages incorporated with carrot and onion, Mendiratta et al., (2013) in vegetable incorporated mutton nuggets, Kaur et al., (2015) in chicken nuggets, Zargar et al., (2017) in chicken sausages and Bhaskar Reddy et al., (2018) in chicken meat nuggets.

In conclusion the incorporation of vegetables has a great potential for improvement of nutritional value of developed products besides several health beneficial effects. Based on the above results it can concluded that addition of $10 \%$ raw radish paste has higher physico-chemical and proximate characteristics and superior sensory scores scored than control and other levels of raw radish pasted added turkey meat sausages and 10 per cent addition of raw radish pasted was optimized for processing of turkey meat sausages with better quality.

\section{References}

Association of Official Analytical Chemists (AOAC). 1995. Official methods of analysis16th Ed. Virginia, USA: Association of Official Analytical Chemist.

Bhaskar Reddy GV, B.Obula Reddy, J. Indumathi and A. Ravi. 2018. Quality characteristics of functional chicken meat nuggets extended with flax seed flour. Indian Journal of Poultry Science, 53(2): 219-224.

Brauer, MC. 1994. Fat reduced frankfurtertype sausage. A technology for preventing too firm and rubbery a bite. Fleischwirtschaft 73: 64-65.

Castro Ferreira, MM., Morgano, MA.,
Nascimento de Queiroza, SC. and Mantovani, DMB. 2000. Relationships of the minerals and fatty acid contents in processed turkey meat products. Journal of Food Chemistry, 69:259-265.

Chang, C.C., Yang, J.H., Chou, C.K. and Tseng, T. 2010. Effect of replacing pork lard with carrot and onion on the quality of Chinese style sausage. Journal of the Agricultural Association of Taiwan, 11: 374-386.

Das, A., Nath, D.R., Kumari, S. and Saha, R. 2013. Effect of fermented bamboo shoot on the quality and shelf life of nuggets prepared from desi spent hen. Veterinary World, 6: 419-423.

Esaki H., and Onozaki H. 1982. Antimicrobial action of pungent principles in radish root. Journal of Japanese Society Food Nutrition.35:207-211.

Grigelmo-Miguel, and Abadias-Seros, MI. and Martin-Belloso, OC. 1999. Characterization of low-fat high dietary fibre frankfurters. Meat Science, 52: 247-256.

Gushi, Y., L. Yujiu, C. Xiuquing and L. Jiehua. 1983. Vitamin C content in vegetables and fruits brought from Shenyang market. Acta NutrimentaSinica, 5(4):373-379.

Kaur M, Kumar A, Kumar S, Hakeem HR, Gupta S. 2015. Effect of carrot on quality characteristics of chicken nuggets. Indian Veterinary Journal. 92(4):44-47.

Katsuzaki H., Miyahara Y., Ota M., Imai K., Komiya T. 2004. Chemistry and antioxidative activity of hot water extract of Japanese radish (daikon). Biofactors.21:211-214.

Keeton, 1983. Effects of fat and $\mathrm{NaCl}$ or phosphate levels on the chemical and sensory properties of pork patties. Journal of Food Science, 48:878-881.

Mendiratta SK, Shinde AT and Mane BG. 
2013.Effect of added vegetable (carrot, radish and capsicum) as functional ingredients in mutton nuggets. Journal of Meat Science and Technology, 1(2): 71-76

Murphy, EW., Criner, PE., and Gray, BC. 1975. Comparisons of methods for calculating retentions of nutrients in cooked foods. Journal of Agricultural Food Chemistry, 23: 1153-1157.

Otles, S. and Cagindi, O. 2008. Fatty acid composition of turkey meat sucuk (soudjuck), salami and sausages. International Journal of Food Engineering. 4:1-6.

Serdaroglu, M. 2006. The characteristics of beef patties containing different levels of fat and oat flour. International Journal of Food Science and Technology, 41: 147-153.

Takaya Y., Kondo Y., Furukawa T., Niwa M. 2003. Antioxidant constituents of radish sprout (Kaiware-daikon), Raphanus sativus L. Journal of Agriculture Food Chemistry51: 8061-8066.

Townsend, WE., LP. Witnauer, J.A. Rillof and CE. Swift. 1968. Comminuted meat emulsion: Different thermal analysis for fat transition. Food Technology, 22:319-323.
Trout, ES., Hunt, MC., Johnson, DE., Claus, JR., Kastner, C.L., Kropf, DH., and Stroda, S. 1992. Chemical, physical, and sensory characterization of ground beef containing 5 to 30 percent fat. Journal of Food Science, 57: 25-29.

Verma, AK., Banerjee, R. and Sharma, BD. 2012. Quality of low fat chicken nuggets: Effect of sodium chloride replacement and added chickpea (Cicer arietinum L.) hullflour. Asian Australasian Journal of Animal Science, 25:291-298.

Verma, AK., Rajkumar, V., Banerjee, R., Biswas, S. and Das, AK.2013. Guava (Psidium guajava L.) powder as an antioxidantdietary fiber in sheep meat nuggets. Asian Australasian Journal of Animal Science, 26: 886-895.

Yue, X. 2001. Perspective of $21^{\text {st }}$ century of functional foods: bridiging Chinese medicated diet and functional foods. International Journal of Food Science and Technology 36: 229-242.

Zargar FA, Kumar S, Bhat ZF and Kumar P. 2017. Effect of incorporation of carrot on the quality characteristics of chicken sausages. Indian Journal of Poultry Science 52(1): 91-95.

\section{How to cite this article:}

Naveen Kumar Reddy, M., M. Shashi Kumar, G. V. Bhaskar Reddy, N. Krishnaiah, N. Anitha Reddy and Maheswara Reddy, D. 2020. Process Optimization of Turkey Meat Sausages by using Raw Radish Paste. Int.J.Curr.Microbiol.App.Sci. 9(07): 1815-1821.

doi: https://doi.org/10.20546/ijcmas.2020.907.208 